larger than usual, the cusps very prominent and sharp. The premolar and molar series of the two sides converge before and behind; the curve continued forward would fall within the anterior teeth. The mandibular premolar inclines very slightly outward. In $D$. lumholtzi the incisor lies in a line with the inferior edge of the mandible, whereas in $D$. dorianus it is tilted greatly upwards. Unlike what is found in other species, the ascending rami, and more especially the coronoid processes, converge rapidly above, and are thus accommodated to the very narrow intertemporal area.

A comparison shows that the skull is by far the largest representative of the genus; the intemporal breadth and the diastema are, however, actually less than in other species.

These points together with the peculiar teeth, the bulging frontals - infinitely more marked than in $D$. lumholtzi-the sagittal crest and other features, show that the cranium is as distinct as the external aspect of the animal. The examination of an immature skull only, can show the amount of development the crest undergoes during the lifetime of the animal.

The aggregate characters of the skull indicate a further stage than has been reached by other species in the progress of differentiation from a radical stock.

\title{
Note on A SEMI-ALBINO SPECIMEN OF DACELO GIGAS.
}

\author{
By Alfred J. North, F.L.S.
}

(Ornithologist to the Australian Museum.)

ONe of the most interesting of the recent additions to the Ornithological Collection is a semi-albino example of Dacelo gigas procured at "Thirribir," Boggabri, New South Wales, by Mr. F. J. Parks during the month of June, and which has been presented by that gentleman to the Trustees. As the bird was received in the flesh and is in perfect plumage, I have taken the opportunity of describing it.

General colour above and below pure white; a spot in front of the eye, and a broad line extending from the gape to the earcoverts, dull rufous; ear-coverts rufous-brown with white shaftlines; median portion of the lengthened crest-feathers and an indistinct nuchal spot, dull rufous; scapulars and interscapular region slightly washed with brown, the lower back faintly barred with brown; rump and upper tail coverts dull rusty-rufous, the 
former indistinctly barred with silvery-blue, the latter with white ; tail white, the two centre feathers freckled with dull rufous on their basal portion and irregularly barred with the same colour except at the tips; remainder of the tail-feathers barred alternately with rufous and brown cross-bars for three-fourths of their length, the bars decreasing in extent towards the outermost feathers where the rufous bars are entirely lost and the brown bars become narrow zigzag lines except at the base; primaries pale brown, white at the base; secondaries pale brown, broadly edged with white on their inner webs ; bastard wing, primary and greater wing-coverts brown, the innermost series of the latter white; median wing-coverts pale brown, the outermost series largely tipped with white and the innermost series with silvery-white; lesser wing-coverts pale brown with whitish tips; axillaries and under primary-coverts white, barred with dusky-brown; remainder of the under wing-coverts white, narrowly and indistinctly barred with dusky-brown. Upper mandible brown, the lower fleshywhite; iris rich reddish-brown; legs and feet pale yellowishbrown. Total length, $17 \cdot 3$ in. ; wing, 9 in. ; tail, 7 in. ; culmen, 2.45 in. ; tarsus, 1.05 inch. Sex $q$ ad., Reg. No. 0-8269.

Of the albino specimens of $D$. gigus in the Museum, the finest example was sent by an unknown donor from Berrima in 1892 . This hird has the whole of the plumage snow-white, with the exception of one or two of the inner and concealed plumes of the ear-coverts which are dark brown; bill dull yellowish-white, with a few short patchy streaks of blackish-brown; legs and feet yellow. In another albino specimen obtained at Bowral, and presented to the Trustees by the Hon. W. A. Long in 1890, the only trace of its normal plumage is likewise in the concealed plumes of the ear-coverts, and in a few brown feathers among the lesser wing-coverts.

The tendency to partial or total albinism apparently exists more in this species than in any other Australian bird, judging by the number of examples represented in the Collection.

In answer to an inquiry of the Curator's asking for further information regarding this specimen, Mr. Parks writes as follows : "The semi-albino Great Kingfisher I sent you was accidentally poisoned by eating mice that had been destroyed by strychnine, and was found by one of my men. I had been preserving this bird for some years, which used to feed at the door and nest in a tree close to the house, and was very sorry when the poor fellow died; at the same time I was glad that it was found before it was too far decayed to preserve as a rara avis." 


\section{$2 \mathrm{BHL}$ Biodiversity Heritage Library}

North, Alfred J. 1895. "Note on a semi-albino specimen of Dacelo gigas." Records of the Australian Museum 2, 87-88.

https://doi.org/10.3853/j.0067-1975.2.1895.1202.

View This Item Online: https://www.biodiversitylibrary.org/item/31634

DOI: https://doi.org/10.3853/j.0067-1975.2.1895.1202

Permalink: https://www.biodiversitylibrary.org/partpdf/4623

\section{Holding Institution}

Harvard University, Museum of Comparative Zoology, Ernst Mayr Library

\section{Sponsored by}

Harvard University, Museum of Comparative Zoology, Ernst Mayr Library

\section{Copyright \& Reuse}

Copyright Status: NOT_IN_COPYRIGHT

This document was created from content at the Biodiversity Heritage Library, the world's largest open access digital library for biodiversity literature and archives. Visit BHL at https://www.biodiversitylibrary.org. 